\title{
A VUELTAS CON LA UTILIDAD DEL RECURSO DE CASACIÓN EN EL ORDEN CONTENCIOSO- ADMINISTRATIVO
}

\author{
BACK WITH THE UTILITY OF THE CASSATION APPEAL IN \\ THE ADMINISTRATIVE JURISDICTION
}

WALTER REIFARTH MUÑOZ*

\section{Resumen}

El presente trabajo pretende abordar críticamente la reforma del recurso de casación en el orden contencioso-administrativo, operada por la Ley Orgánica 7/2015, de 21 de julio, de modificación de la Ley Orgánica del Poder Judicial, con especial atención a los aspectos procedimentales y al interés casacional objetivo a que se refiere dicha norma, piedra angular del nuevo sistema. Para ello, se considera necesario analizar previa y sucintamente las funciones del recurso de casación y las limitaciones a su acceso para emprender después el estudio los problemas procesales y sustantivos que puede conllevar dicha reforma.

\section{Palabras Clave}

Recurso de casación; orden contencioso-administrativo; Tribunal Supremo; admisibilidad; interés casacional.

\begin{abstract}
In this paper, we critically address the reform of cassation appeal (recurso de casación) on the contentious-administrative jurisdiction carried out by Act $\mathrm{n}^{\mathrm{o}} 7 / 2015$ of $21^{\text {th }}$ July, which amends the Judiciary (Organization) Act. We will focus on the procedural aspects and the appeal interest, one of the
\end{abstract}


cornerstones of the new system. In doing so, it is considered necessary to briefly analyze the functions of the cassation appeal and its access constraints first, then undertake the study of the procedural and substantive problems that the aforementioned reform may entail.

\section{Keywords}

Cassation appeal; contentious-administrative jurisdiction; Supreme Court; admissibility; cassational interest.

\section{INTRODUCCIÓN}

En España, el recurso de casación en el orden contencioso-administrativo no se incorporó al abanico de medios de impugnación hasta la Ley 10/1992, de 30 de abril, de medidas urgentes de reforma procesal. Con anterioridad, la Sala Tercera del Tribunal Supremo, cúspide judicial en este orden, había asumido con carácter general la competencia para resolver los recursos de apelación contra ciertas resoluciones de la Audiencia Nacional, los Tribunales Superiores de Justicia y las ya suprimidas Audiencias Territoriales. Ya desde ese momento, el legislador pretendió crear un medio de impugnación efectivo cuya finalidad básica fuera la creación y custodia de pautas interpretativas uniformes que exige la seguridad jurídica de todo Estado de Derecho. Sin embargo, se mantuvieron determinados aspectos del carácter subjetivo de un recurso que, en última instancia, está destinado a resolver las pretensiones deducidas por las partes en conflictos previos mediante la confirmación o la anulación, total o parcial, de la decisión judicial impugnada.

La Ley Orgánica 7/2015, de 21 de julio, de modificación de la Ley Orgánica 6/1985, de 1 de julio, del Poder Judicial, contiene reformas procesales de hondo calado, como la eliminación de la responsabilidad civil directa de jueces y magistrados, nuevas posibilidades de especializar

Artículo recibido para su evaluación el 7 de mayo de 2020, y aprobado para su publicación el 15 de julio de 2020.

* Personal investigador en formación en el Área de Derecho Procesal de la Universidad de Salamanca (España) gracias a las Ayudas destinadas a financiar la contratación predoctoral de personal investigador de la Junta de Castilla y León y el Fondo Social Europeo (Orden EDU/574/2018, de 28 de mayo). Este trabajo ha sido realizado en el marco de una estancia de investigación de mayo a julio de 2019 en el Centro de Estudios Políticos y Constitucionales (Madrid, España). Email: reifarth@usal.es. 
uno o varios órganos judiciales de modo temporal y con carácter exclusivo si así lo exige el cúmulo de asuntos, el mecanismo para la ejecución de las sentencias del Tribunal Europeo de Derechos Humanos o el encaje definitivo de la jurisdicción militar en el Poder Judicial, entre otras muchas. Pero, sin duda, una de las modificaciones más importantes es la que afecta al sistema casacional contencioso-administrativo con el objetivo, como advierte el Preámbulo de la Ley, de asegurar la uniformidad en la aplicación judicial del Derecho e intensificar las garantías en la protección de los derechos de los ciudadanos. En la consecución de tan loable fin, la reforma diseña un mecanismo de admisión de los recursos de casación que pivota sobre el concepto de interés casacional objetivo $\mathrm{y}$ hace desaparecer las anteriores limitaciones del acceso al recurso por razón de la materia y la cuantía.

Este trabajo indaga, a través del método jurídico, en la nueva configuración del recurso de casación en el orden contenciosoadministrativo, con especial énfasis en los criterios de admisibilidad, las resoluciones impugnables y las diferentes fases del recurso. Con ello, se pretende ofrecer una visión panorámica de una reforma que ha querido dejar atrás los remedios coyunturales a un problema sistémico y que ha transformado de forma aguda la caracterización de este medio de impugnación como lo conocíamos hasta entonces.

\section{EL RECURSO DE CASACIÓN EN EL ORDEN CONTENCIOSO- ADMINISTRATIVO Y LA NECESIDAD DE SU REFORMA}

Cualquier estudio crítico que pueda considerarse fundado sobre la reforma del sistema casacional en el orden contencioso-administrativo debe venir precedido, con carácter necesario, por el análisis de las funciones del recurso de casación, así como por la descripción del contexto y de la dirección de una modificación de tan profundo calado. No se busca con ello profundizar en una materia inabarcable por sí misma, sino exponer de forma sucinta algunas ideas comunes en esta materia, porque el juicio sobre la reforma va a estar profundamente condicionado por el conocimiento de las circunstancias concurrentes y, sobre todo, por la mayor significación, objetiva o subjetiva, que se le quiera dar al recurso en cada caso.

\section{Concepto y funciones del recurso de casación}


El Tribunal Supremo, en cuanto tribunal de casación, tiene una función sustancialmente distinta a la que se encomienda al resto de órganos jurisdiccionales, por más que en todos ellos, en la interpretación del Derecho y la formación de jurisprudencia, operen en general mediante la resolución de los concretos conflictos jurídicos que se les presentan. Para Calamandrei, los tribunales de casación proyectan su actividad sobre la aplicación de la ley desarrollada por los tribunales inferiores en grado ${ }^{1}$. Así, cuando el Tribunal Supremo resuelve litigios secundum ius, controla al propio tiempo la relación entre la función legislativa y la función jurisdiccional. Por tanto, corresponde a los tribunales de casación la función constitucional de nomofilaquia por la que "se trata de mantener [a] los órganos jurisdiccionales en la esfera de su poder, destruyendo las sentencias que hayan sido pronunciadas fuera de los límites del mismo"2.

Como es sabido, el recurso de casación es un recurso extraordinario, sustanciado en términos generales ante el Tribunal Supremo, contra las resoluciones definitivas que dictan los órganos jurisdiccionales inferiores a fin de examinar la aplicación del Derecho que estos hacen en el ejercicio de su función. Siendo extraordinario, no cabe contra todas las resoluciones judiciales, sino solo aquellas a las que el ordenamiento permite su acceso a la casación, y tampoco puede considerarse un grado jurisdiccional que permita un nuevo examen de todas y cada una de las cuestiones conocidas por el órgano de instancia. Por estas razones, el recurso de casación se ha diferenciado tradicionalmente de otros medios de impugnación por la determinación de motivos o circunstancias que limitan su interposición. Con ello, se persigue la custodia del ordenamiento jurídico mediante el mantenimiento de una jurisprudencia uniforme y la anulación de las resoluciones contrarias a él ${ }^{3}$.

El recurso de casación debe alcanzar toda cuestión que resulte relevante para el conjunto de la sociedad, con independencia de su procedencia y

1 CALAMANDREI, Piero: La casación civil, tomo II. Editorial Bibliográfica Argentina, Buenos Aires, 1945. p. 29.

2 Ibídem, p. 57. También se ha advertido de los resultados devastadores para la utilidad del recurso que ha tenido la deformación de las ideas del insigne procesalista italiano por parte de la más autorizada doctrina: NIEVA FENOLL, Jordi: "La relevancia social de la casación: la importancia del ius litigatoris", en Jurisdicción y proceso. Marcial Pons, Madrid, 2009. pp. 479-503.

3 Para profundizar en la identidad del recurso de casación como medio de garantizar el cumplimiento de la ley y de una interpretación uniforme a través de la defensa de los intereses que las partes traen al proceso, véase también CHIOVENDA, Giuseppe: Principios del Derecho Procesal Civil, tomo II. Reus, Madrid, 1925. pp. 533 y ss. 
cuantía, ya que, en el orden jurisdiccional que nos interesa aquí, debe permitir que el Tribunal Supremo se pronuncie sobre "los grandes temas jurídico-administrativos de nuestro país y sobre otros más pequeños pero de indudable trascendencia para dotar de uniformidad interpretativa a todo el ordenamiento jurídico"4.

El debate sobre la verdadera función que debe cumplir el recurso de casación no es nuevo y muchas veces se ha planteado con cierto maniqueísmo. En los últimos años, la doctrina más extendida es la que defiende que el recurso de casación debe estar más orientado a la depuración de la aplicación del ordenamiento jurídico (ius constitutionis o función nomofiláctica) que a la protección de los intereses del ciudadano (ius litigatoris). Ello parece derivar de la creencia de que los órganos judiciales supremos del mundo anglosajón dictan pocas sentencias, pero de gran autoridad, en comparación con sus homólogos en el civil law, que sufren una excesiva carga de trabajo derivada del ingente número de asuntos que están obligados a conocer y resolver, con el correspondiente retraso en su terminación y la mayor probabilidad de que existan resoluciones contradictorias $^{5}$. Además, la necesidad de mantener una jurisprudencia uniforme obliga a mantener la unicidad de los tribunales supremos en sus respectivos ordenamientos, cuya contrapartida suele ser una sobrecarga que puede poner en peligro la utilidad de sus mandatos.

La armonía entre ambas tendencias no se ha alcanzado, y lo cierto es que la concepción de los tribunales de casación como órganos protectores del ordenamiento no es en absoluto incompatible con que el individuo que acuda a ellos pueda beneficiarse de aquella función nomofiláctica para la mejor tutela de su interés privado mediante el reenvío del asunto resuelto por el tribunal de instancia. En mi opinión, lo verdaderamente antagónico es más bien la disolución de estos dos rostros de la casación, porque uno no

4 CÓRDOBA CASTROVERDE, Diego: "Por un nuevo modelo del recurso de casación en materia contencioso-administrativo". En: Revista de Jurisprudencia, 1 de diciembre de 2013.

5 NIEVA FENOLL, Jordi: Derecho Procesal II: Proceso civil. Tirant lo Blanch, Valencia, 2019. pp. 337-338. La mayor relevancia que se da a la custodia de la norma mediante el recurso de casación no es solo propia de los círculos doctrinales, sino que también se ha extendido a los magistrados de los tribunales supremos. Así, en consonancia con la nueva configuración que se le ha querido dar al recurso, se ha dicho que la función nomofiláctica "impide atender a situaciones concretas, particulares o patológicas, debiendo — por el contrario- considerarse situaciones generales y aplicables a un gran número de sujetos" (Auto del Tribunal Supremo 909/2019, de 8 de enero de 2019, FJ 3. ${ }^{\circ}$ ). 
puede operar sin el otro. El equilibrio entre ambas funciones es el verdadero reto de la construcción del mecano jurídico.

\section{Antecedentes y razones para una reforma del sistema casacional.}

El aumento del número de litigios en todos los órdenes jurisdiccionales, incluido el contencioso-administrativo, lleva aparejada la acumulación de los recursos de casación y, en consecuencia, una dilación a veces excesiva en su sustanciación ${ }^{6}$. En este contexto, el legislador ha ido introduciendo requisitos especiales de admisibilidad del recurso, que no solo no lograron solucionar el problema, sino que, peor aún, han terminado deformando por completo la función de la casación, como se verá .

En este sentido, con anterioridad al año 2015, solo podían acceder al recurso de casación las sentencias dictadas en instancia única por la Audiencia Nacional y los Tribunales Superiores de Justicia de las Comunidades Autónomas, excluyendo así las sentencias dictadas en apelación ante estos órganos y, por supuesto, las emanadas de los Juzgados unipersonales de lo contencioso-administrativo. Junto a este requisito de procedencia, se instauró un mecanismo sustantivo, o un "factor de corrección”, en palabras del Alto Tribunal ${ }^{8}$, en función de la cuantía de

6 La Sala Tercera de lo Contencioso-Administrativo del Tribunal Supremo tenía antes de la reforma la siguiente carga de trabajo:

\begin{tabular}{|c|c|c|c|c|}
\hline Año & Ingresados & Resueltos & Pendientes & $\begin{array}{c}\text { Tiempo medio de res- } \\
\text { puesta (meses) }\end{array}$ \\
\hline 2013 & 5.045 & 6.583 & 6.475 & 15,5 \\
2014 & 5.475 & 5.872 & 6.465 & 14,7 \\
2015 & 8.803 & 5.947 & 9.381 & 13,8 \\
\hline
\end{tabular}

Fuente: Elaboración propia a partir de las "Estadísticas del Consejo General del Poder Judicial sobre la eficiencia del Tribunal Supremo" (Disponible en: http://www. poderjudicial.es/cgpj/es/Poder-Judicial/Tribunal-Supremo/Portal-de-Transparencia/Tepuede-interesar---/Estadisticas-/).

7 El Tribunal Constitucional ha considerado que estas limitaciones no lesionan el derecho a la tutela judicial efectiva. Nuestro exégeta constitucional tuvo la oportunidad de señalar que "[e]l sistema de recursos se incorpora a la tutela judicial en la configuración que le dé cada una de esas leyes de enjuiciamiento reguladoras de los diferentes órdenes jurisdiccionales, sin que ni siquiera exista un derecho constitucional a disponer de tales medios de impugnación, siendo imaginable, posible y real la eventualidad de que no existan, salvo en lo penal [...] El establecimiento y regulación, en esta materia, pertenece al ámbito de libertad del legislador". Cfr. STC 37/1995, de 7 de febrero, FJ 5.․․

8 Véase, por todas, la Sentencia del Tribunal Supremo de 25 de marzo de 2010. 
la pretensión, progresivamente en aumento, que pretendía hacerse valer a través del recurso de casación. Estos especiales y objetivos requisitos de procedencia y admisibilidad del recurso diseñados por el legislador procesal buscaban, sin éxito, blindar al Tribunal Supremo de una posible avalancha de recursos que le impidiera resolverlos con todas las exigencias del debido proceso y, en particular, aquellas relativas a los plazos razonables y la prohibición de las dilaciones indebidas (art. 24.2 CE) ${ }^{9}$.

En la búsqueda de soluciones a los problemas planteados, la Sección Especial para la reforma de la Ley de la Jurisdicción Contencioso Administrativa, creada en el seno de la Comisión General de Codificación para abordar, entre otros, los problemas relativos al acceso de asuntos y la casación en este orden, presentó en 2013 su "Informe explicativo y propuesta de ley de eficiencia de la Jurisdicción Contencioso Administrativa". En este exhaustivo estudio, se puso de manifiesto que "el recurso de casación, en la suma de sus modalidades, no es — en la actualidad - un instrumento procesal idóneo para la formación de jurisprudencia», y ello porque, por un lado, "son muchas las materias o asuntos que - fundamentalmente por las reglas de cuantía - no tienen acceso a la casación", y, por otro, porque el recurso «no está primariamente dirigido a la creación de jurisprudencia, sino a la tutela de intereses, derechos o competencias (por lo demás, de alto nivel económico)" (página 63 del Informe). Dada la ineficiencia del modelo, y atendiendo a la legislación comparada y a otros antecedentes más remotos de sugerencias de mejora ${ }^{10}$, la Sección Especial desarrolló una proposición normativa consistente, entre otros aspectos, en suprimir la delimitación objetiva de las sentencias recurribles, simplificar la tipología de los recursos, convertir el interés casacional en el nervio central del nuevo sistema de admisión e introducir la mediación administrativa como

9 Sobre las garantías constitucionales dimanantes del derecho fundamental al recurso, véanse PICÓ I JUNOY, Joan: Las garantías constitucionales del proceso (2. ${ }^{\mathrm{a}}$ ed.). Bosch, Barcelona, 2012, esp. pp. 97 y ss.; y LETELIER LOYOLA, Enrique: El derecho fundamental al recurso en el proceso penal. Atelier, Barcelona, 2013. esp. pp. 139 y ss.

10 Nos referimos aquí a la "Exposición razonada, relativa al proyecto de Ley Orgánica que modifica la Ley reguladora de la Jurisdicción contencioso-administrativa y reforma el recurso de casación", suscrita en 2006 por veintiún Magistrados entonces integrantes de la Sala Tercera del Tribunal Supremo. En ella, se propuso como remedio "el uso del interés casacional como razón única para que la Sala Tercera de dicho Tribunal conozca de las impugnaciones de sentencias pronunciadas por cualquier órgano jurisdiccional del orden contencioso-administrativo, cuya definición o concreción puede reservarse el legislador o ser encomendada al propio Tribunal como en otros sistemas judiciales de comprobada eficacia y prestigio" (pp. 3-4 de la Propuesta). 
posible instrumento de evitación de litigios ${ }^{11}$. Gran parte de las propuestas, como se verá, fueron tomadas en cuenta con ocasión de la reforma de 2015.

\section{ORIENTACIONES GENERALES SOBRE LA REFORMA DE LA CASACIÓN CONTENCIOSO-ADMINISTRATIVA}

Como se ha venido sosteniendo, el nuevo modelo casacional, que recuerda en parte al sistema del writ of certiorari del Tribunal Supremo estadounidense ${ }^{12} \mathrm{o}$ a la objetivación del recurso de amparo constitucional que trajo la Ley Orgánica 6/2007, de 24 de mayo ${ }^{13}$, pretende descongestionar al Tribunal Supremo de los asuntos que debe conocer. Con independencia de la función de la casación a la que se quiera poner el acento, el anterior sistema no era eficiente: primero, porque contábamos con un recurso destinado a la resolución de litigios de muy elevada cuantía, de los cuales muchos carecían de interés para la sociedad por versar sobre normas reiteradamente interpretadas por el Tribunal; segundo, porque la exigencia de unanimidad y de motivación en la resolución de inadmisión de un recurso con pocos visos de prosperar exigía un esfuerzo con frecuencia superior al de su propia desestimación; y tercero, porque asuntos verdaderamente relevantes para la comunidad jurídica no podían acceder a la casación por no alcanzar la cuantía mínima exigida o por quedar fuera de su ámbito objetivo.

Con el propósito de corregir estas ineficiencias, la Ley Orgánica 7/2015, de 21 de julio, por la que se modifica la Ley Orgánica 6/1985, de

11 Sobre este último aspecto, que la Sección propone para futuras reformas y cuya amplitud desborda las ambiciones perseguidas en este trabajo, véase MARTÍN DIZ, Fernando: Mediación en el ámbito contencioso-administrativo. Aranzadi, Cizur Menor, 2018.

12 Sobre las similitudes entre ambos sistemas, véase PÉREZ ALONSO, Jorge: "El nuevo sistema de casación en el orden contencioso-administrativo operado por la Ley Orgánica 7/2015, de 21 de julio: con la vista puesta en el certiorari estadounidense". En: Diario La Ley, núm. 8621 Sección Doctrina, de 8 de octubre de 2015. Conviene señalar que la mayoría de los países que cuentan con un sistema casacional cercano al español han venido legislando para aliviar la carga jurisdiccional de sus respectivos tribunales de casación. Así, por ejemplo, en Alemania se exige desde el año 2001 que el recurso de revisión presentado ante el Bundesgerichtshof se fundamente en interés de la ley con el fin de lograr la unidad de la doctrina jurisprudencial.

13 La referida Ley introdujo la figura, algo desconcertante, de la "especial relevancia constitucional" en el trámite de admisión del recurso de amparo ante el Tribunal Constitucional, de manera que la sustanciación del recurso solo tiene cabida cuando el proceso suscite cuestiones que contengan oscuridades de difícil resolución o necesitadas de revisión sobre el ámbito y significado de los derechos fundamentales, cuando posea un interés que trascienda del estricto ámbito de las partes o cuando permita sentar pautas interpretativas nuevas para la protección y delimitación de los derechos fundamentales. 
1 de julio, del Poder Judicial, introduce en su disposición final tercera una importante modificación de la Sección 3. ${ }^{a}$ del Capítulo III del Título IV de la Ley 29/1998, de 13 de julio, reguladora de la jurisdicción contenciosoadministrativa (LJCA, en lo sucesivo) en torno al sistema casacional en este orden jurisdiccional.

Además de la introducción del interés casacional objetivo que, por su importancia, merece atención aparte, esta reforma está gobernada por una serie vectores que, en conjunto, vienen a reforzar la función del recurso de asegurar la unidad en la interpretación y aplicación del Derecho y que pasamos a comentar seguidamente ${ }^{14}$.

\section{La unificación de las modalidades de recursos.}

La primera de las direcciones que ha tomado la mencionada reforma es la supresión de los motivos extraordinarios del recurso de casación en interés de ley y para la unificación de doctrina. Se mantiene así únicamente el recurso de casación, para cuya resolución será competente el Tribunal

14 Son inabarcables los trabajos que han puesto de relieve esta dirección. Véanse, a título ejemplificativo y al margen de los demás estudios oportunamente citados, RAZQUIN LIZARRAGA, José Antonio: "El recurso de casación en la jurisdicción contenciosoadministrativa tras la Ley Orgánica 7/2015”. En: Revista Vasca de Administración Pública, núm. 104, 2016, quien considera que la Ley viene a otorgar a la Sala Tercera del Tribunal Supremo "un poder total sobre su trabajo para que pueda encontrar su papel como tribunal de casación para la formación y uniformidad de la jurisprudencia". p. 176). También MAYOR GÓMEZ, Roberto: "Compendio sobre el recurso de casación contencioso-administrativo introducido por la Ley Orgánica 7/2015, de 21 de julio, por la que se modifica la Ley Orgánica 6/1985, de 1 de julio, del Poder Judicial”. En: Gabilex. Revista del Gabinete Jurídico de la Junta de Comunidades de Castilla-La Mancha, núm. 7, septiembre de 2016; RODRÍGUEZ CARBAJO, José Ramón: "Las diez claves de los nuevos recursos de casación contencioso-administrativos". En: Diario La Ley, núm. 8809, 22 de julio de 2016; RUIZ LÓPEZ, Miguel Ángel: La reforma del recurso de casación contencioso-administrativa. Tirant lo Blanch, Valencia, 2016; HINOJOSA MARTÍNEZ, Eduardo: El nuevo recurso de casación contencioso-administrativo. Bosch, Barcelona, 2015; HUELÍN MARTÍNEZ DE VELASCO, Joaquín: "La nueva casación contencioso-administrativa (primeros pasos)". En: Revista General de Derecho Constitucional, núm. 24, 2017; CANCIO FERNÁNDEZ, Raúl César: El nuevo recurso de casación en el orden contencioso-administrativo. Aranzadi, Cizur Menor, 2015; SOLDEVILA FRAGOSO, Santiago: "Las paradojas de la nueva casación". En: Actualidad administrativa, núm. 10, 2016; TRIANA REYES, Belén (2016): "La que se nos viene encima con la casación contencioso-administrativa". En: Diario La Ley, núm. 8733, Sección Tribuna, 4 de abril de 2016; PÉREZ UREÑA, Antonio Alberto: "El nuevo recurso de casación contencioso-administrativo". En: Revista de Jurisprudencia, núm. 1, octubre de 2015, entre otros modos. 
Supremo, que podrá interponerse por cualquier «concreta infracción del ordenamiento jurídico, tanto procesal como sustantiva, o de la jurisprudencia» (art. 88.1 LJCA).

Aunque se mantiene el recurso limitado a la cognición de "cuestiones de Derecho, con exclusión de las cuestiones de hecho" (art. 87 bis), en la resolución de la controversia, el Tribunal Supremo podrá integrar en los hechos admitidos como probados por la Sala de instancia "aquellos que, habiendo sido omitidos por esta, estén suficientemente justificados según las actuaciones y cuya toma en consideración resulte necesaria para apreciar la infracción alegada de las normas del ordenamiento jurídico o de la jurisprudencia, incluso la desviación de poder" (art. 93.3) ${ }^{15}$.

\section{Una pingüe ampliación de las resoluciones recurribles en casación.}

Como ya se ha tenido ocasión de indicar, el nuevo modelo suprime la estricta delimitación objetiva de las sentencias recurribles que regía antes, de manera que potencialmente podrán serlo todas ${ }^{16}$.

En particular, además de las sentencias dictadas en única instancia por las Salas de lo contencioso-administrativo de la Audiencia Nacional y de los Tribunales Superiores de Justicia de las Comunidades Autónomas, se podrá interponer recurso de casación contra las sentencias para las que no proceda recurso de apelación — las dictadas por los Juzgados de lo contencioso-administrativo o por los Juzgados Centrales de lo contenciosoadministrativo en única instancia, siempre que contengan «doctrina que se repute gravemente dañosa para los intereses generales y sean susceptibles de extensión de efectos» (art. 86.1 LJCA) - y contra las sentencias dictadas por las Salas de lo contencioso-administrativo de la Audiencia

15 Sobre este particular, véase BETANCOR, Andrés: La revisión casacional de la prueba en el contencioso-administrativo. Cívitas, Madrid, 2012, que nota los problemas que, para la efectividad de la tutela judicial, pueden derivarse del hecho de que la revisión de la valoración de la prueba, incluso tasada, "no tiene lugar en la práctica, dando lugar a una material prohibición de la revisión". p. 65.

16 Se excluye expresamente las sentencias cuyo objeto sean el derecho fundamental de reunión y aquellas que versen sobre Derecho electoral, ya que gozan de un cauce procesal específico (art. 86.2 LJCA). Específicamente ha trabajado sobre esta ampliación y las dudas que puede suscitar, CANCER MINCHOT, Pilar: "La nueva casación contenciosa: dudas interpretativas que suscitan las sentencias y autos susceptibles de recurso". En: Actualidad Jurídica Aranzadi, núm. 917, 2016. p. 19. De la misma autora, "La nueva casación contenciosa- administrativa: sentencias y autos recurribles. El interés casacional objetivo”. En: Revista Aranzadi Doctrinal, núm. 6, 2016. pp. 41-62. 
Nacional y de los Tribunales Superiores de Justicia al resolver recursos de apelación contra las sentencias emanadas de los juzgados de este orden jurisdiccional ${ }^{17}$.

Como ocurría con anterioridad a la reforma, cuando se recurran en casación las sentencias dictadas por las Salas de lo contenciosoadministrativo de los Tribunal Superiores de Justicia, será necesario invocar una «infracción de normas de Derecho estatal o de la Unión Europea que sea relevante y determinante del fallo impugnado, siempre que hubieran sido invocadas oportunamente en el proceso o consideradas por la Sala sentenciadora» (art. 86.3 LJCA). Si el recurso se funda en una infracción de normas autonómicas, seguirá siendo competente una Sección de la Sala de lo contencioso-administrativo del Tribunal Superior de Justicia compuesta por el presidente de dicha Sala, que la presidirá, por el presidente o presidentes de las demás Salas de lo contencioso-administrativo y, en su caso, de las Secciones de las mismas, en número no superior a dos, y por los magistrados de la referida Sala o Salas que fueran necesarios para completar un total de cinco miembros (art. 86.3 in fine $)^{18}$.

Así, admitiéndose potencialmente el recurso contra cualesquiera sentencias dictadas en única o segunda instancia, es apreciable la ampliación horizontal de la casación, que asegura que cualquier asunto que pueda revestir interés para la ciudadanía pueda ser objeto de una interpretación uniforme por parte del Tribunal Supremo.

Anteriores reformas legislativas, como las operadas con motivo de la aprobación de la LJCA y de la Ley 37/2011, de 10 de octubre, de medidas de agilización procesal, apostaron por aumentar la cuantía como requisito objetivo para acceder a la casación ${ }^{19}$. Aunque se tratara de un criterio cierto para el control de la admisibilidad del recurso, no constituía una solución real y efectiva frente a la elevada litigiosidad en sede casacional y, además, conducía a una completa desnaturalización del recurso, ya que la cuantía debatida en un litigio - al igual que la procedencia de la resolución impugnada — poco o nada dice sobre la trascendencia social de su objeto.

17 La reforma no introduce modificaciones respecto a la situación anterior en lo que se refiere a los Autos (art. 87 LJCA). No obstante, la nueva redacción sigue exigiendo la interposición del «recurso de súplica», sustituido en el año 2009 por el recurso de reposición, lo que prueba, una vez más, la deficiente técnica legislativa.

18 Sobre este último caso, véase CUDERO BLAS, Jesús: «El recurso de casación por infracción de normas autonómicas». En: Revista de Jurisprudencia, 1 de julio de 2016.

19 La primera norma mencionada elevó la cuantía de 36.000 euros a 150.000; la segunda, a 600.000 euros. 
Por ello, aunque la ampliación no está exenta de opiniones en diverso sentido y ha venido acompañada de refinadas propuestas de mejora ${ }^{20}$, la doctrina ha valorado positivamente esta supresión de las anteriores limitaciones del acceso a la casación, que coadyuva al correcto despliegue de su función protectora del ordenamiento.

\section{Una adaptación imperiosa de las formas.}

El apartado tercero del art. 87 bis LJCA, en línea con el rigorismo formal con que se pretende dotar al recurso, introduce la novedad de que la Sala de Gobierno del Tribunal Supremo pueda determinar mediante acuerdo, que habrá de publicarse en el Boletín Oficial del Estado, la extensión máxima y otras cuestiones extrínsecas, incluidas las relativas a su presentación por medios telemáticos, de los escritos de interposición y de oposición de los recursos de casación. No obstante, los motivos que justifican el establecimiento de normas e instrucciones formales para tales escritos sirven también, siquiera a modo de recomendación, respecto de todos los escritos que se puedan presentar durante la tramitación del recurso, como es el escrito de preparación sobre el que se profundizará más adelante ${ }^{21}$.

En este sentido, se ha venido a aprobar el Acuerdo de 20 de abril de 2016, de la Sala de Gobierno del Tribunal Supremo, sobre la extensión máxima y otras condiciones extrínsecas de los escritos procesales referidos al recurso de casación ante la Sala Tercera del Tribunal Supremo, donde se

20 Considera MESTRE DELGADO, Juan Francisco: "La configuración del recurso de casación en torno al interés casacional". En BAÑO LEÓN, José María (coord.): Memorial para la Reforma del Estado: estudios en homenaje al profesor Santiago Muñoz Machado (t. I). Centro de Estudios Políticos y Constitucionales, Madrid, 2016, que la elección del legislador "debería haberse basado en un análisis o en una ponderación más detallada de las resoluciones susceptibles de ser recurridas" y que "podría haber sido adecuado permitir la impugnación de cualquier auto o sentencia, de forma que sea el Tribunal el que determine en cada caso, atendiendo a su singularidad, si existe o no interés casacional objetivo con la finalidad de formal jurisprudencia para la protección de las normas". p. 1023.

21 Con todo, el Tribunal Europeo de Derechos Humanos, en Sentencia de 19 de diciembre de 1997, en el asunto Brualla Gómez de la Torre c. España, tiene dicho que, para la aplicación del art. 6 del Convenio [derecho a un proceso equitativo], hay que tener en cuenta "el conjunto del proceso presentado ante el orden jurídico y el papel que ha desempeñado la jurisdicción suprema, así como las condiciones de admisión del recurso pudiendo ser más rigurosas [para la casación] que para una apelación" y que, dado el específico papel que desempeña el Tribunal Supremo como autoridad jurídica más alta del sistema judicial, se puede admitir "que se observe un mayor formalismo en el procedimiento que se presenta ante este". párrs. 37-38. 
han fijado cuestiones tan prolijas como la extensión máxima de los escritos, el tipo de fuente, el interlineado, los márgenes o la sangría ${ }^{22}$.

La posibilidad de fijar de forma minuciosa las características formales del escrito constituye una novedad el ordenamiento español, derivada de una previsible complejidad técnica en aumento de los escritos y de la observación a las experiencias de otros tribunales de nuestro entorno. En este sentido, son varios los órganos jurisdiccionales que disponen de normas que regulan, de forma muy detallada, la extensión máxima, el formato y estructura de los escritos que se presentan ante ellos, así como las consecuencias que se pueden derivar de su incumplimiento ${ }^{23}$.

La justificación que se ha dado a este mayor rigor formal es doble: por un lado, facilitar la lectura y análisis de los escritos relativos a la tramitación del recurso por parte del órgano sentenciador y del Tribunal Supremo; por otro, establecer una estructura y un formato uniformes que pueda simplificar el procedimiento presentación telemática y posterior tratamiento digital, permitiendo una rápida localización del propósito del escrito y de los datos de identificación de los recurrentes, en línea con la Ley 18/2011, de 5 de julio, reguladora del uso de las tecnologías de la información y la comunicación en la Administración de Justicia ${ }^{24}$. Téngase

22 La Comisión Permanente del Consejo General del Poder Judicial, en su reunión de 19 de mayo de 2016, acordó hacer público el acuerdo de la Sala de Gobierno del Tribunal Supremo, en su reunión de 20 de abril de 2016, sobre la extensión máxima y otras condiciones extrínsecas de los escritos procesales referidos al recurso de Casación ante la Sala Tercera de este Tribunal (Boletín Oficial del Estado, núm. 162, de 6 de julio de 2016. pp. 47539-47543.

23 Así, por ejemplo, los respectivos Reglamentos de Procedimiento del Tribunal General y el Tribunal de Justicia de la Unión Europea regulan de forma pormenorizada las indicaciones que deben contener los escritos que se presenten ante ellos, su extensión máxima, su numeración, formato, tipo de letra, forma de identificación de anexos adjuntos, etc. De igual modo, el artículo 47 del Reglamento de Procedimiento del Tribunal Europeo de Derechos Humanos fija las condiciones formales para recurrir ante ese tribunal, exigiendo que toda demanda se presente en un formulario facilitado por la Secretaría del Tribunal, al que se le puede adjuntar un documento con una extensión máxima, formato, tipo de letra y márgenes determinados. También las Reglas de la Corte Suprema de Estados Unidos contienen un minucioso régimen de presentación de los escritos procesales, referidos al tamaño y color del papel, tipo de fuente, forma de citar las disposiciones y la jurisprudencia y una severa limitación del número de palabras que se pueden utilizar en relación con cada tipo de escrito. El incumplimiento de estas reglas conlleva automáticamente la inadmisión de las peticiones o alegaciones.

24 El artículo 36.4 de la Ley 18/2011, de 5 de julio, establece que «todo escrito iniciador del procedimiento deberá ir acompañado de un formulario normalizado debidamente cumplimentado en los términos que se establezcan reglamentariamente», y su artículo 
en cuenta, no obstante, que estos argumentos deben ser colegidos con la doctrina constitucional que, sobre la base del principio pro actione, proscribe las decisiones de inadmisión que, por su rigorismo, formalismo excesivo o cualquier otra razón, releven una clara desproporción entre los fines que las causas de inadmisión preservan y los intereses de las partes que se sacrifican ${ }^{25}$.

\section{EL INTERÉS CASACIONAL OBJETIVO: UNA CÓMODA CORAZA PARA LA INADMISIÓN DE RECURSOS}

El núcleo de la reforma objeto de nuestro análisis es la figura del «interés casacional objetivo» como presupuesto de admisión del recurso de casación ${ }^{26}$. Aunque el concepto no es del todo nuevo y tiene una clara inspiración en la casación civil ${ }^{27}$, en el orden contencioso-administrativo presenta una serie de peculiaridades sobre las que merece la pena detenerse. En última instancia, el interés casacional está dirigido a la «formación de jurisprudencia», entendida esta como la creación de doctrina jurisprudencial

38.1 dispone que «la presentación de toda clase de escritos, documentos, dictámenes, informes u otros medios o instrumentos se ajustará a lo dispuesto en las leyes procesales, debiendo ir acompañados en todo caso del formulario normalizado a que se refiere el apartado 4 del art. 36, en el que además se consignará el tipo y número de expediente y año al que se refiera el escrito».

25 El Tribunal Constitucional ha rechazado la interpretación rigorista de las normas procesales que resulte irrazonable o manifiestamente desproporcionada con la finalidad para la que se han establecido. Véanse, entre otras, las Sentencias del Tribunal Constitucional 121/2019, de 28 de octubre (FJ 3. ${ }^{\circ}$ ); 91/2016, de 9 de mayo (FFJ 3. ${ }^{\circ}$ y $5 .^{\circ}$ ); 149/2015, de 6 de julio (FJ 3..$^{\circ}$ ); 39/2010, de 19 de julio (FJ 3..$^{\circ}$ ); 105/2006, de 3 abril $\left(\mathrm{FJ} 3 .^{\circ}\right)$. El Tribunal Supremo ha estimado en varias ocasiones el recurso de queja presentado por los recurrentes en este sentido. Así, en los Autos 5973/2017, de 12 de junio; 6869/2017, de 4 de julio; o 10653/2017, de 13 de noviembre.

26 MUÑOZ ARANGUREN, Antonio: "La curiosidad del jurista persa y la reforma del recurso de casación contencioso-administrativo". En: Diario La Ley, núm. 8634, de 28 de octubre de 2015, considera que con el adjetivo «objetivo» se ha querido enfatizar el carácter nomofiláctico de la casación por oposición al ius litigatoris del que ya se ha hablado, si bien quizá tal adjetivo no sea el más adecuado.

27 Según el artículo 477.3 de la Ley de Enjuiciamiento Civil, Se considerará que un recurso presenta interés casacional «cuando la sentencia recurrida se oponga a la doctrina jurisprudencial del Tribunal Supremo o resuelva puntos y cuestiones sobre los que exista jurisprudencia contradictoria de las Audiencias Provinciales o aplique normas que no lleven más de cinco años en vigor, siempre que, en este último caso, no existiese doctrina jurisprudencial del Tribunal Supremo relativa a normas anteriores de igual o similar contenido». En el orden civil, también resulta ilustrativo el Acuerdo de la Sala Primera del Tribunal Supremo de 30 de diciembre de 2011. pp. 13-17. 
en materias donde no existía o la consolidación o modificación de la ya sentada.

Así, el art. 88 de la reformada LJCA recoge una serie de supuestos en que el Tribunal Supremo podrá admitir el recurso de casación, con lo que se sustituye el anterior sistema de admisión reglado por otro potestativo en el que el Tribunal deberá a apreciar la concurrencia, o no, del interés casacional objetivo del recurso.

Téngase en cuenta que ninguna de las situaciones contempladas en este artículo, incluidas aquellas para las se presume la existencia de interés casacional, determina por sí misma la admisión del recurso. El precepto está sin duda construido con el propósito de conceder al Tribunal Supremo un amplio margen de discrecionalidad, aunque no absoluto, a la hora de decidir qué asuntos merecen ser conocidos y resueltos por él. Más que motivos tasados de admisión del recurso, nos encontramos ante una numeración de carácter enunciativo y no exhaustivo en la propia norma que permite a los recurrentes fundamentar su pretensión en ciertos supuestos $\operatorname{arquetípicos}^{28}$. $\mathrm{Al}$ análisis de los mismos dedicaremos las próximas líneas.

\section{Legislar a golpe de ejemplario: el artículo 88.2 LJCA.}

El apartado segundo del art. 88 LJCA relaciona una serie de supuestos en los que el Tribunal Supremo «podrá» apreciar que la cuestión suscitada en el recurso presenta interés casacional objetivo. Se trata, como ya se ha señalado, de una lista abierta («entre otras circunstancias», como dice el precepto), de forma que la parte recurrente pueda invocar otras circunstancias no contempladas en ella siempre que haga una cuidada y rigurosa justificación del interés casacional que esgrime ${ }^{29}$.

28 A este respecto, se ha señalado con razón la «innegable antinomia» jurídica entre el art. 88 y el art. 89.2.f) LJCA. Este último obliga especialmente a los recurrentes a alegar alguna de las causas genéricas mencionadas en la disposición anterior para acceder a la casación. Cfr. MUÑOZ ARANGUREN, cit, p. 4.

29 Como señalan, entre otros muchos, los Autos del Tribunal Supremo 7286/2018, de 18 de junio (FJ 3. ${ }^{\circ}$ ); 3503/2018, de 2 de abril (FJ 2. ${ }^{\circ}$ ); 2189/2017, de 15 de marzo (FJ 2..$^{\circ}$ : "El carácter abierto de la enumeración de circunstancias que permiten apreciar la presencia de interés casacional objetivo para la formación jurisprudencia, conforme a lo dispuesto en el artículo 88.2 LJCA, conduce a entender que a este Tribunal Supremo puede reputar existente el interés casacional objetivo del recurso preparado con sustento en otras circunstancias distintas, no contempladas en ese artículo 88.2 LJCA, ni tampoco incluidas en el artículo 88.3 LJCA, y, por ende, que el recurrente también podrá invocarlas para justificar el interés casacional objetivo del recurso de casación 
a) La contradicción entre criterios interpretativos.

El primer y más frecuente supuesto de interés casacional, contemplado en el art. 88.2.a) LJCA, se refiere a la sentencia impugnada que "fije, ante cuestiones sustancialmente iguales, una interpretación de las normas de Derecho estatal o de la Unión Europea en las que se fundamenta el fallo contradictoria con la que otros órganos jurisdiccionales hayan establecido".

El precepto viene a sustituir la anterior y desafortunada regulación del recurso de casación para la unificación de doctrina, para el que, sin embargo, se exigía una rigurosa identidad de hechos que había terminado por reducirlo a la inutilidad ${ }^{30}$. Cabe ahora la acreditación de diferencias o contradicciones entre las resoluciones objeto de contraste, siempre que presenten una similitud sustancial con respecto a las normas aplicadas y a la realidad sobre la que estas se proyectan ${ }^{31}$. Para cumplir esta carga procesal, no bastará con afirmar que existe una contradicción, sino que: "[A la parte recurrente] le es exigible razonar y justificar argumentalmente la igualdad sustancial de las cuestiones examinadas en las sentencias que se someten a contraste, mediante un razonamiento que explique que, ante un problema coincidente de interpretación del ordenamiento jurídico aplicable al pleito, la sentencia impugnada ha optado por una tesis hermenéutica divergente, contradictoria e incompatible con la seguida en la sentencia de contraste" ${ }^{32}$.

En suma, la invocación de este motivo exige argumentar de forma circunstanciada por qué la cuestión litigiosa examinada en la sentencia impugnada recibe una solución distinta a la resolución de contraste, que no tendrá que ser firme ${ }^{33}$. El razonamiento deberá estar, en todo caso,

preparado. La excepcionalidad de la invocación de estas otras circunstancias de interés casacional en la configuración legal del recurso de casación [...] exige del recurrente que en el escrito de preparación justifique cuidada y rigurosamente el interés casacional objetivo del recurso que revela la circunstancia invocada".

30 SANTAMARÍA PASTOR, Juan Alfonso: "La orientación legal acerca del interés casacional: excesos y defectos del artículo 88”. En: Revista de Administración Pública, núm. 207, 2018. p. 48.

31 Véanse, como los más recientes, Autos del Tribunal Supremo 5831/2020, de 23 de julio (FJ 2. ${ }^{\circ}$ ); 5816/2020, de 17 de julio (FJ 3. ${ }^{\circ}$ ); 5811/2020, de 15 de julio (FJ 1. ${ }^{\circ}$ ); 3113/2020, de 21 de mayo (FJ $1 .^{\circ}$ ), entre muchos otros. El Auto 190/2019, de 17 de enero, completa lo anterior al expresar que «aun cuando tal identidad no es del grado antaño exigido para el extinto recurso de casación para la unificación de doctrina, no significa que la identidad sustancial exigible se diluya hasta extremos de admitir una mera relación indirecta o puramente teórica» (FJ 2. ${ }^{\circ}$ ).

32 Auto del Tribunal Supremo 720/2017, de 7 de febrero (FJ 3. ${ }^{\circ}$ ).

33 Señala GONZÁLEZ-VARAS IBÁÑEZ, Santiago José: Tratado de Derecho Administrativo (3. ${ }^{a}$ ed.) (t. II). Aranzadi, Cizur Menor, 2018, p. 973, que las sentencias 
circunscrito a las pautas hermenéuticas divergentes que se han seguido en cada resolución, sin que quepa extender el contraste a cuestiones distintas ${ }^{34}$.

b) Daño grave a los intereses generales o afectación a un gran número de situaciones.

El art. 88.2.b) LJCA configura el supuesto de interés casacional consistente en que la resolución impugnada siente una doctrina sobre las normas de Derecho estatal o de la Unión Europea "que pueda ser gravemente dañosa para los intereses generales". Por su parte, la letra c) hace lo propio respecto de la sentencia que "afecte a un gran número de situaciones, bien en sí misma o por trascender del caso objeto del proceso".

El concepto de grave daño al interés general es altamente indeterminado y justifica las matizaciones que sobre él ha ido introduciendo el Tribunal Supremo al resolver los sucesivos asuntos. En estos casos, el interés casacional viene dado cuando la doctrina se repute lesiva para los intereses generales, con independencia de la cuantía debatida en el proceso $^{35} \mathrm{o}$ de que provoque una reducción de los ingresos en las arcas públicas ${ }^{36}$. Con todo, la parte recurrente deberá expresar las razones por las que considera

de contraste deberán ser firmes, porque esa era la postura que se siguió en los primeros autos tras la entrada en vigor del nuevo sistema casacional. Sin embargo, la Sala Tercera ya admite el contraste con resoluciones no dotadas aún de firmeza.

34 Auto del Tribunal Supremo 7295/2018, de 25 de junio (FJ 1. ${ }^{\circ}$ ): "No basta, por lo tanto, con invocar supuestos sustancialmente iguales y que se haya llegado a pronunciamientos distintos o contrarios, sino que es preciso justificar que tal resultado contradictorio se ha producido precisamente como consecuencia de una distinta interpretación de la norma y no por otras causas como la valoración de la prueba, o circunstancias fácticas que, aun aplicando el mismo criterio jurídico doctrinal, determinen un fallo distinto. Es preciso, por lo tanto, justificar, que ante supuestos sustancialmente iguales el criterio jurídico doctrinal seguido resulta contradictorio sin que baste con referir un resultado o pronunciamiento distinto en el fallo".

35 Como expresa el Auto del Tribunal Supremo 274/2017, de 25 de enero (FJ 2. ${ }^{\circ}$ ): "[E]1 interés casacional viene dado cuando la doctrina sentada, que no la cuantía debatida, es gravemente dañosa para los intereses generales".

36 Así en el Auto del Tribunal Supremo 2759/2017, de 5 de abril (FJ 2. ): “[L]a afirmación, sin más, de que una determinada doctrina provoca una reducción de los ingresos fiscales del Estado no lleva como consecuencia automática que sea gravemente dañosa para el interés general, pues, desde la perspectiva fiscal, este último no consiste en obtener una mayor recaudación (mero "interés recaudatorio"), sino en obtener la recaudación que derive de la realización de un sistema tributario justo, mediante la puesta en práctica de los principios que proclama el artículo 31 de la Constitución Española (verdadero "interés general")". Esta doctrina ha sido recogida también en los Autos 4789/2020, de 30 de junio; 9295/2019, de 26 de septiembre; y 2765/2017, de 5 de abril. 
dañosa la doctrina en cuestión, relacionándola con la realidad afectada por ella y sin que sean suficientes afirmaciones genéricas e imprecisas en tal sentido.

Por su parte, la afección a un gran número de situaciones habrá de contemplarse a la luz de la virtualidad expansiva de la doctrina que se combate en casación ${ }^{37}$, y deberá ser acreditada por la parte recurrente mediante un análisis que exteriorice la previsible influencia de tal doctrina en muchos supuestos, sin que sean suficientes las afirmaciones abstractas y genéricas que supongan sin más dicha afección o que la deriven de la interpretación de las normas jurídicas que, por su naturaleza intrínsecas, son aplicables a un número indeterminado de situaciones ${ }^{38}$.

\section{c) La validez de las normas.}

Dispone el art. 88.2.d) LJCA que el Tribunal Supremo podrá apreciar que existe interés casacional objetivo, motivándolo expresamente en el auto de admisión, cuando la resolución que se impugna "resuelva un debate que haya versado sobre la validez constitucional de una norma con rango de ley, sin que la improcedencia de plantear la pertinente cuestión de inconstitucionalidad aparezca suficientemente esclarecida". Para ello, deberá tenerse en cuenta si existió un debate en la instancia sobre la procedencia de plantear la cuestión de inconstitucionalidad, si había dudas fundadas sobre la constitucionalidad de la norma concernida y si la resolución impugnada no dio respuesta alguna a la petición de planteamiento de dicha cuestión ante el Tribunal Constitucional ${ }^{39}$. Por su parte, la letra g) se refiere a los casos en que la resolución atacada «resuelva un proceso en que se impugnó, directa o indirectamente, una disposición

37 Como se expone en el Auto 715/2017, de 1 de febrero, "[p]ara apreciar la presencia de esta circunstancia de interés casacional se debe atender de forma prioritaria a la virtualidad expansiva de la doctrina sentada por la sentencia recurrida, que en el caso de autos ni resulta diáfana ni se concreta, más allá de los cuarenta y ocho recursos presentados por la misma entidad recurrente -según informa- y del nítido interés subjetivo de esta que su existencia pone de manifiesto". En el mismo sentido, Autos 2583/2019, de 7 de marzo (FJ 1. ${ }^{\circ}$ ); 168/2019, de 16 de enero (FJ 2. ${ }^{\circ}$ ); 11219/2018, de 24 de octubre (FJ 4..$^{\circ}$ ); 9014/2018, de 12 de septiembre (FJ 6. ${ }^{\circ}$ ).

38 Entre otros, Autos del Tribunal Supremo 3189/2020, de 28 de mayo (FJ 4. ${ }^{\circ}$ ); 11113/2019, de 24 de octubre (FJ 2. ${ }^{\circ}$ ); 7011/2018, de 25 de junio (FJ 4. ${ }^{\circ}$ ); y 1802/2017, de 8 de marzo (FJ 2. ${ }^{\circ}$ )

39 El Tribunal Supremo se ha pronunciado sobre estas consideraciones en los recientes Autos 4420/2020, de 11 de junio; 3452/2020, de 4 de junio; y 688/2020, de 27 de enero. 
de carácter general $»^{40}$. Ambos supuestos se refieren, pues, a procesos en que lo controvertido es la validez de una norma legal o reglamentaria, respectivamente.

\section{d) La defensa de la doctrina jurisprudencial constitucional y europea.}

La Ley Jurisdiccional hace descansar sobre el Tribunal Supremo la correcta aplicación e interpretación de la jurisprudencia constitucional y europea, permitiéndole apreciar concurrente el interés casacional cuando la sentencia impugnada interprete y aplique una doctrina constitucional "aparentemente con error y como fundamento de su decisión" (art. 88.2.e) o el Derecho de la Unión Europea "en contradicción aparente con la jurisprudencia del Tribunal de Justicia o en supuestos que aun pueda ser exigible la intervención de este a título prejudicial" (art. 88.2.f).

En ambos casos, no basta con la manifestación de que existe una discrepancia jurídica o la mera referencia a las resoluciones contradictorias con el fallo de la sentencia que se impugna en casación, sino que el recurrente deberá argumentar por qué se trata de supuestos iguales y en qué forma se ha adoptado un criterio diferente, esto es, deberá argumentar de qué manera la resolución que se impugna ha interpretado aquellas doctrinas jurisprudenciales con error o en contradicción aparente ${ }^{41}$.

40 Es necesario precisar que la relación que existe entre el art. 88.2.g) y 88.3.c) LJCA es, según el Tribunal Supremo, una relación de "especificidad", en el sentido de que el segundo es más específico que el primero. Así, entre otros, en los Autos del Tribunal Supremo 1783/2020, de 25 de febrero (FJ 2. ${ }^{\circ}$ ); 12316/2017, de 15 de octubre (FJ 2. ${ }^{\circ}$ ).

41 En el primer caso, la parte recurrente deberá cumplir "los requisitos contenidos en el citado artículo 88.2.e), a saber: i) qué interpretación o aplicación de la doctrina constitucional ha realizado a juicio del recurrente el órgano jurisdiccional a quo; ii) qué razón conduce a pensar que la doctrina constitucional se ha aplicado por error; y iii) cómo se verifica que todo ello ha constituido el fundamento de la decisión alcanzada (entre otros, Auto del Tribunal Supremo 10680/2018, de 1 de octubre, FJ $1 .^{\circ}$ ). En cuanto a la letra f) del referido artículo, quien sostiene su concurrencia «bajo la tesis de que se ha contradicho la jurisprudencia del Tribunal de Justicia de la Unión Europea, debe: i) identificar con suficiente precisión las resoluciones del TJUE que, según se afirma, interpretan el Derecho de la Unión Europea de forma contradictoria con la interpretación seguida en la resolución judicial que se impugna; ii) exponer el objeto o contenido de esas resoluciones sometidas a contraste y explicar en qué medida son, como se afirma, contradictorias; iii) razonar la incidencia de la divergencia interpretativa del Derecho europeo así puesta de manifiesto sobre el sentido del "fallo" de la resolución judicial combatida en casación; y iv), en definitiva, fundamentar la pertinencia de esa comparación entre la resolución judicial combatida en casación y la del TJUE que supuestamente la contradice" (entre otros, Auto del Tribunal Supremo 2123/2019, de 1 de marzo, FJ 4. ${ }^{\circ}$ ). 
e) Las resoluciones relativas a convenios interadministrativos.

El art. 88.2.h) LJCA también establece como posible manifestación de interés casacional cuando la sentencia atacada "resuelva un proceso en que lo impugnado fue un convenio celebrado entre Administraciones Públicas" ${ }^{\prime 2}$.

La inclusión de esta circunstancia únicamente puede justificarse en el intento de proteger el adecuado funcionamiento del principio de cooperación interadministrativa ${ }^{43}$, pues el contenido de tales acuerdos puede ser enormemente variado y, en la mayoría de los casos, es dudoso que pueda tener relevancia desde el punto de vista social y jurídico para la formación de jurisprudencia; cuestión esta que habrá de ser ponderada en cada caso por la Sección de admisiones. Por otro lado, aunque el artículo se refiera únicamente a la impugnación de convenios, el Tribunal Supremo ha tenido ocasión de extender su alcance también a los casos de la aplicación y ejecución de los acuerdos para cuya resolución se requiere la interpretación y cotejo del contenido de su contenido ${ }^{44}$.

f) Las resoluciones relativas al procedimiento especial de protección de derechos fundamentales.

El último supuesto que relaciona el art. 88.2 LJCA es el referido a la resolución impugnada "que haya sido dictada en el procedimiento especial de protección de derechos fundamentales", destinado a tutelar los derechos fundamentales frente a las actuaciones sujetas al Derecho administrativo.

No existen dudas sobre la importancia de estos derechos, no solo para el ciudadano, sino también para la construcción de una jurisprudencia que

42 Para comprender la noción, tipología y funcionamiento de estos convenios, es necesario acudir a los artículos 47 a 53 de la Ley 40/2015, de 1 de octubre, de Régimen Jurídico del Sector Público.

43 GARCÍA GÓMEZ DE MERCADO, Francisco; YAÑEZ DÍAZ, Carlos; VIZÁN PALOMINO, María: El recurso de casación contencioso-administrativo conforme a la Ley Orgánica 7/2015. Comares, Granada, 2016. p. 141.

44 En este sentido, Auto del Tribunal Supremo de 22 de febrero de 2019 (FJ 3. ${ }^{\circ}$ ): "Es cierto que en el presente recurso de casación no se suscita directamente una cuestión relativa a los términos del citado convenio y su interpretación, pero también lo es que la eventual calificación como actos de ejecución del Convenio de los acuerdos para los que se solicita la ampliación de medidas cautelares, sí requiere de su interpretación y de su cotejo con el contenido del citado Convenio Marco. No se puede excluir, por tanto, que el ámbito del supuesto de interés casacional objetivo previsto en el artículo 88.2.h) LJCA pueda proyectarse, en un caso como el ahora analizado, sobre todas aquellas actuaciones que se produzcan en relación con el Convenio impugnado y sus efectos". 
aspire a integrar y depurar el ordenamiento con vocación de permanencia ${ }^{45}$. El presupuesto jurídico para que opere este apartado no es la vulneración de derechos fundamentales en sí misma, sino la tramitación del proceso de instancia por el cauce especial que regulan los arts. 114 a 122 ter $\mathrm{LJCA}^{46}$. Nótese, por lo demás, que el hecho de que la sentencia impugnada haya recaído en este tipo de procesos de amparo ordinario constituye un indicio, dotado de especial fuerza por cuanto los órganos jurisdiccionales del orden administrativo son los jueces ordinarios de tutela de los derechos fundamentales ${ }^{47}$, pero no implica la admisión automática del recurso, ya que pesa sobre los recurrentes la carga de justificar este extremo mediante una referencia circunstanciada al caso controvertido y al concreto derecho fundamental afectado ${ }^{48}$.

\section{Las presunciones del artículo 88.3 LJCA.}

A fin de evitar o, al menos, dificultar la elección absolutamente libérrima de los asuntos que merecen ser atendidos por la Sala Tercera del Tribunal Supremo, el legislador procesal ha introducido, en el apartado tercero del art. 88 LJCA, una lista cerrada de supuestos para los que se presume el interés objetivo para la formación de jurisprudencia: a) cuando en la resolución impugnada se hayan aplicado normas en las que se sustente la razón de decidir sobre las que no exista jurisprudencia ${ }^{49}$; b) cuando dicha

45 No obstante, se han planteado dudas sobre la verdadera utilidad de la inclusión de esta letra i) en SANTAMARÍA PASTOR, cit., pp. 54-55: "Conferir interés casacional a las sentencias en el procedimiento especial de protección de derechos fundamentales, por otra parte, tampoco se me antoja razonable. Para empezar, dejemos a un lado el hecho de que la mayor parte de los conflictos que utilizan esta vía procesal, en la actualidad, son de una relevancia general bastante escasa [...] T] ambién, que la interpretación de los preceptos constitucionales ha sido ya exhaustivamente hecha por el diluvio de sentencias dictadas por el Tribunal Constitucional hasta el cierre del recurso de amparo, por lo que raramente concurrirá la conveniencia de que el Tribunal Supremo se pronuncie en casación sobre alguno de ellos".

46 Auto del Tribunal Supremo 8138/2019, de 15 de julio (FJ 3. ${ }^{\circ}$ ).

47 Auto del Tribunal Supremo 3460/2019, de 18 de marzo (FJ 2. ${ }^{\circ}$ ).

48 Véanse, entre los más recientes, los Autos del Tribunal Supremo 5162/2020, de 3 de julio (FJ 1. ${ }^{\circ}$ ); 5053/2019, de 30 de abril (FJ 1. ${ }^{\circ}$ ); y 3673/2018, de 9 de abril (FJ 2. ${ }^{\circ}$ ).

49 El Auto del Tribunal Supremo 10011/2017, de 30 de octubre, se pronuncia en este sentido: "[N]o basta para que concurra la presunción con razonar que sobre el particular supuesto examinado en la resolución recurrida no existe jurisprudencia, porque la formación de jurisprudencia obedece necesariamente a parámetros más generales y a la interpretación de las normas jurídicas para su común aplicación. De ahí la necesidad de justificar siempre en el escrito de preparación la conveniencia de que el Tribunal 
resolución se aparte deliberadamente de la jurisprudencia existente al considerarla errónea ${ }^{50} ; \mathrm{c}$ ) cuando la sentencia recurrida declare nula una disposición de carácter general, salvo que esta, con toda evidencia, carezca de trascendencia suficiente ${ }^{51}$; d) cuando resuelva recursos contra actos o disposiciones de los organismos reguladores o de supervisión o agencias estatales cuyo enjuiciamiento corresponde a la Sala de lo contenciosoadministrativo de la Audiencia Nacional; e) cuando resuelva recursos contra actos o disposiciones de los Gobiernos o Consejos de Gobierno de las Comunidades Autónomas. A pesar de este sistema presuntivo, el art. 88.3 in fine LJCA señala que, en los supuestos referidos en las letras a), d) y e), el recurso podrá ser inadmitido «por auto motivado cuando el Tribunal aprecie que el asunto carece manifiestamente de interés casacional objetivo para la formación de jurisprudencia».

Supremo se pronuncie sobre la cuestión planteada. La invocación retórica de un precepto y la mera afirmación de que sobre el mismo no existe jurisprudencia resulta, pues, totalmente insuficiente para integrar el contenido de esta presunción legal de interés casacional objetivo" (FJ 2. ${ }^{\circ}$ ).

50 La jurisprudencia ha venido exigiendo que la invocación de esta presunción exige "justificar que se ha producido un apartamiento de la jurisprudencia "deliberado", esto es, expreso, consciente y reflexivo. Y es que para una adecuada invocación de esta presunción de interés casacional no basta con denunciar una mera inaplicación de la jurisprudencia por el órgano de instancia, sino que la parte recurrente ha de justificar en el escrito de preparación lo que el apartado 3.b) exige, a saber: que el órgano judicial de instancia, en su resolución, (i) hizo mención expresa de la jurisprudencia, (ii) señaló que la conocía y la valoró jurídicamente, y (iii) se apartó expresamente de ella por entender que no es correcta" (Auto del Tribunal Supremo 11313/2019, de 31 de octubre, FJ 1. ${ }^{\circ}$, entre otros).

51 Esta presunción viene a proteger, con buen criterio, una interpretación uniforme de las disposiciones de carácter general, pero introduce una salvedad ("con toda evidencia") que necesita ser matizada. El Auto del Tribunal Supremo 3001/2017, de 8 de marzo señala que "el precepto exige que la disposición anulada cuente, con toda evidencia, con trascendencia suficiente. Lo que no cabe predicar de una ordenanza fiscal como la declarada nula en la instancia, relativa a la tasa por ocupación del dominio público en un municipio que cuenta con 1.998 habitantes [...], a lo que debe añadirse que el fallo de la sentencia de apelación precisa que la nulidad afecta específicamente a lo debatido, esto es, a la utilización privativa del vuelo sobre el dominio público por empresas operadoras del sector eléctrico. Es decir, se trataría de una cuestión concreta y delimitada, por lo que no es posible entender que la disposición cuente con la pretendida y evidente trascendencia suficiente», y que «el hecho de que concurra un supuesto de presunción de interés casacional no conlleva, de forma automática, que se deba admitir el recurso de casación, como parece dar a entender el Ayuntamiento recurrente, siendo preciso, así mismo, que la parte recurrente [...] fundamente, con especial referencia al caso, por qué considera que en ese supuesto concreto existe interés casacional objetivo, que exija un pronunciamiento por parte de este Tribunal Supremo" (FJ 3. ${ }^{\circ}$ ). 
La confusa redacción del precepto ha suscitado no pocas dudas interpretativas en torno a la naturaleza de la presunción. Aunque hay quien ha considerado que se trata de un conjunto de presunciones iure et de iure ${ }^{52}$, me inclino a pensar que la norma introduce una cualificación de ciertas circunstancias merecedoras de un pronunciamiento del Tribunal Supremo, pero en ningún caso inatacables. Puede abonar esta interpretación, en primer lugar, el hecho de que la tercera presunción del listado, que podría considerarse la más próxima a una de tipo absoluto ${ }^{53}$, puede ser también enervada cuando la disposición anulada por la sentencia impugnada carezca de trascendencia suficiente «con toda evidencia»; y, en segundo lugar, el art. 90.3.b) LJCA, que exige la inadmisión mediante auto en estos supuestos, no hace distingos entre ellos. Además, se compadecería mal con el espíritu de la reforma la obligatoria admisión a trámite del recurso con base en la sola invocación, siquiera formal, de la concurrencia de alguno de los dos apartados.

No obstante, creo que la cuestión no puede ser objeto de conjeturas o hipótesis doctrinales, sino que debe quedar claramente determinada por el legislador mediante la depuración de la letra de un artículo que, además de envolver conceptos oscuros ("jurisprudencia", "apartamiento deliberado"...), no define el verdadero alcance de las presunciones que contiene.

\section{PREPARACIÓN, ADMISIÓN Y SUSTANCIACIÓN DEL RECURSO DE CASACIÓN}

En las próximas líneas abordaremos, también de forma crítica, las distintas fases del recurso de casación en el orden contencioso-

52 MUÑOZ ARANGUREN, Antonio: op. cit., p. 4, entiende que esta interpretación está abonada por varias razones: a) la redacción dada a la Exposición de Motivos; b) la alusión del art. 90.3.b) LJCA a las «salvedades que [el art. 88.3] establece; c) la diferenciación hecha por el legislador entre los diferentes apartados del art. 88.3 LJCA; y d) la valoración jurídica predeterminada hecha por el legislador al tasar las causas de presunción. En el mismo sentido, HUELÍN MARTÍNEZ DE VELASCO, Joaquín: "El interés objetivo en la nueva casación contencioso-administrativa". En: Anuario de la Facultad de Derecho de la Universidad Autónoma de Madrid, núm. 22, 2018. pp. 375379. Contra esta interpretación, véase MESTRE DELGADO, cit., pp. 1026-1028.

53 CANCIO FERNÁNDEZ, R. C.: "Respuestas a los problemas procesales derivados de la entrada en vigor del nuevo recurso de casación contencioso-administrativo o cuando el recurso de queja dejó de ser arte menor", en CANCIO FERNÁNDEZ, R. C.; CAZORLA PRIETO, L. M. (dirs.): El interés casacional objetivo en su interpretación auténtica: pautas hermenéuticas y cuestiones procesales en la nueva casación contenciosa. Aranzadi, Cizur Menor, 2018. pp. 41-42. 
administrativo tras la reforma introducida por la Ley $7 / 2015$, que mantiene, aunque con sustantivas matizaciones, las del sistema anterior: la fase de preparación del recurso ante la Sala de instancia (1), la fase de admisión ante el Tribunal Supremo (2) y, en caso de admitirse el recurso, la fase de interposición (3).

\section{El escrito de preparación: un mayor protagonismo para la sala de instancia.}

El art. 89 LJCA regula la fase de preparación del recurso de casación, que se residencia en el órgano judicial de instancia por quienes hayan sido o debieran haber sido parte en el proceso. A este respecto, un feliz cambio, dirigido a otorgar a los recurrentes la dedicación y el tiempo necesario para cumplir con el complejo contenido con que se ha dotado a este escrito, es la ampliación del plazo de presentación, que pasa de diez a treinta días.

Se deberá comprobar en esta fase el cumplimiento del plazo y de las reglas de legitimación activa, la recurribilidad de la resolución impugnada $\mathrm{y}$, al propio tiempo, el recurso deberá indicar el conjunto de normas o la jurisprudencia infringida (art. 89.2 LJCA) ${ }^{54}$. Además, en el escrito de preparación deberá también acreditarse la concurrencia en el concreto asunto del interés casacional objetivo $\mathrm{y}$, por tanto, los recurrentes deberán hacer el esfuerzo de subrayar la especial idoneidad de que el Tribunal Supremo invierta esfuerzos para pronunciarse sobre él por su trascendencia social o por los otros motivos ya expuestos que abren el acceso a la casación (art. 89.2 LJCA) $)^{55}$.

54 Reviste singular interés la formalidad de que el recurrente acredite en el escrito la recurribilidad de la resolución impugnada cuando esta sea una sentencia dictada en única instancia por los juzgados de contencioso-administrativo, que únicamente son recurribles en casación si reúnen dos requisitos cumulativos: que contenga doctrina que se repute gravemente dañosa para los intereses generales y que sea susceptibles de extensión de efectos (art. 86.1 LJCA). Como señala el Auto del Tribunal Supremo 9118/2017, de 15 de septiembre, la alusión a la extensión de efectos "no puede entenderse de otra manera que referida a la contemplada en los arts. 110 y 111 de la Ley de esta Jurisdicción. En lo que aquí concierne, el mencionado art. 110 LJCA establece la posibilidad de extender los efectos de una sentencia firme que hubiera reconocido una situación individualizada a favor de una o varias personas, si se ha dictado en materia tributaria, de personal al servicio de la Administración pública o de unidad de mercado y si concurren las circunstancias enumeradas en el precepto" (FJ único).

55 Téngase en cuenta, no obstante, que el apartado tercero del art. 87 bis LJCA permite a la Sala de Gobierno del Tribunal Supremo "determinar, mediante acuerdo que se publicará en el Boletín Oficial del Estado, la extensión máxima y otras condiciones 
Resulta llamativo que, en este punto y a pesar de la supresión parcial de los gravosos requisitos de procedencia para la admisibilidad del recurso de casación, el art. 89 LJCA solo se refiera a los Tribunales Superiores de Justicia, obviando por completo las decisiones de los órganos unipersonales a las que la nueva regulación abre la casación. Se trata, pues, de un descuido del legislador que parece no haber asimilado todavía la ampliación del ámbito objetivo del recurso de casación. No obstante, las dudas que prima facie pueda generar este olvido tienen una importancia relativa, ya que la interpretación sistemática y el espíritu de la norma obligan a incluir en esta desafortunada redacción a los referidos juzgados ${ }^{56}$.

Mayor perplejidad debe despertar el alcance del examen del escrito de preparación por parte de la Sala de instancia, ahora convertida en el dique de contención de la avalancha de recursos que amenaza de forma damóclica con colapsar la Sala Tercera del Tribunal Supremo. ¿Debe el órgano a quo verificar el cumplimiento de todas las exigencias del art. 89.2 LJCA para el acceso a la casación? ¿Con qué límites? Una desafortunada lectura del precepto podría llevar a pensar que el informe potestativo que la Sala de instancia puede unir al oficio de remisión ex art. 89.5 LJCA alcanza también a pronunciarse sobre la concurrencia o no del interés casacional objetivo en el asunto ${ }^{57}$. Lo cierto es, sin embargo, que la apreciación de dicho interés y, con ella, la decisión sobre la admisibilidad del recurso, corresponde en exclusiva al Tribunal Supremo, con independencia de la opinión formada de la Sala sentenciadora. A estas dudas dio temprana

extrínsecas, incluidas las relativas a su presentación por medios telemáticos, de los escritos de interposición y de oposición de los recursos de casación". El incumplimiento de estas exigencias jurisdiccionales en el escrito de preparación tendrá la consideración de defecto insubsanable y, en consecuencia, el recurso se tendrá por no presentado, la sentencia impugnada adquirirá firmeza y se impondrán costas a la parte recurrente, pudiendo tal imposición ser limitada (art. 90.7 LJCA).

56 De la misma opinión, CANCIO FERNÁNDEZ, "Respuestas a los problemas...", cit., p. 31.

57 La doctrina mayoritaria considera que la opinión fundada a la que alude el art. 89.5 LJCA únicamente cabe cuando el órgano sentenciador es favorable a la admisión del recurso. Así, FERNÁNDEZ FARRERES, G.: "Sobre la eficiencia de la jurisdicción contenciosoadministrativa y el nuevo recurso de casación para la formación de jurisprudencia". En: Revista Española de Derecho Administrativo, núm. 174, 2015. pp. 93-132. Pero, ciertamente, la redacción del primer aparatado del art. 90.3 LJCA ("si el órgano que dictó la resolución recurrida hubiera emitido en el trámite que prevé el artículo 89.5 opinión que, además de fundada, sea favorable a la admisión...") parece admitir la interpretación contraria, que mantiene PENÍN ALEGRE, Clara: "La preparación del recurso de casación: un control escurridizo”. En: Revista Jurídica de Castilla y León, núm. 40, 2016. pp. 25-26. 
respuesta el Alto Tribunal al afirmar que: "[A la Sala de instancia] le incumbe, en particular y desde una perspectiva formal, el análisis sobre el cumplimiento de los requisitos de plazo, legitimación y recurribilidad de la resolución, así como la constatación de que en el escrito de preparación hay un esfuerzo argumentativo tendente a la justificación de la relevancia de la infracción denunciada y su carácter determinante del fallo y también, en especial, si se contiene una argumentación específica, con singular referencia al caso, de la concurrencia de alguno o algunos de los supuestos que, conforme a los apartados 2 y 3 del art. 88 LJCA, permiten apreciar el interés casacional objetivo. No le compete, en cambio, enjuiciar si concurre o no la infracción de fondo alegada por el recurrente, como hace aquí la Sala de instancia, ni pronunciarse sobre la efectiva concurrencia de ese interés objetivo casacional que determina la admisión del recurso, pues esa es una función que corresponde en exclusiva a esta Sala (arts. 88 y 90.2 LJCA ). Todo ello sin perjuicio de que el tribunal pueda, si lo considera oportuno, emitir el informe previsto en el art. 89.5 de la LJCA" ${ }^{, 58}$.

Reviste especial interés la doctrina del Alto Tribunal en los supuestos en que el recurso se tuvo por no preparado como consecuencia de una extemporaneidad revocada después por el Tribunal Supremo. En estos casos, si el juicio sobre la preparación del recurso ha estado en todo momento ceñido al carácter intempestivo de su presentación, dato que no necesita de mayor consideración sobre la improcedencia del escrito, una vez descartada esta tacha por el Tribunal Supremo en el correspondiente recurso de queja, el órgano a quo deberá entonces verificar el cumplimiento de los demás requisitos del art. 89.2 LJCA, pues hasta esa devolución del asunto a la instancia no se habían examinado ${ }^{59}$.

Concluido este examen previo, si la Sala de instancia considera que no se cumplen los requisitos del art. 89.2 LJCA, tendrá por no presentado el recurso de casación mediante auto motivado contra el que solo cabe el recurso de queja. En caso de cumplir con las formalidades y los requisitos del escrito, la Sala, también mediante auto motivado, ordenará el emplazamiento de las partes para su comparecencia en el plazo de treinta

58 Auto del Tribunal Supremo 349/2017, de 2 de febrero, que resuelve el recurso de queja núm. 110/2016. Esta dirección jurisprudencial ha sido mantenida por el Tribunal Supremo de forma constante. Véanse, entre los más recientes, los AATS 2147/2020, de 28 de febrero; 1812/2020, de 21 de febrero; 9782/2019, de 26 de septiembre; 9776/2019, de 20 de septiembre; 9185/2019, de 16 de septiembre; 7567/2019, de 4 de julio; y $7263 / 2019$, de 28 de junio.

59 Así, entre otras, Auto del Tribunal Supremo 6872/2017, de 4 de julio. 
días ante la Sala Tercera del Tribunal Supremo y la remisión a esta de los autos originales y del expediente administrativo.

\section{La admisión a trámite.}

Al margen de las cuestiones organizativas de la Sala y los motivos de admisión, ya expuestos al hilo de los temas tratados, el art. 90.1 LJCA establece que, una vez recibidas las actuaciones, no será necesario acordar un previo trámite de audiencia a las partes para que manifiesten su parecer sobre la concurrencia del interés casacional objetivo. No obstante, la ley deja abierta la puerta, con razón por mor de la elevada complejidad de los asuntos que a menudo se residencian en sede casacional, a que la Sección de admisiones de la Sala Tercera del Tribunal Supremo pueda acordar oír a las partes personadas por plazo común de treinta días y solo de forma excepcional si las características del asunto lo aconsejan.

a) La admisión: la publicidad como factor de corrección de los fallos del modelo.

La resolución de admisión adoptará la forma de auto en que se precisará «la cuestión o cuestiones en las que entiende que existe interés casacional objetivo e identificarán la norma o normas que en principio serán objeto de interpretación, sin perjuicio de que la sentencia haya de extenderse a otras si así lo exigiere el debate finalmente trabado en el recurso» (art. 90.4 LJCA). La carga de probar la concurrencia del interés casacional objetivo recae sobre los recurrentes y no sobre el Tribunal ad quem, que se limitará simplemente a valorar las cuestiones alegadas ${ }^{60}$. Para tener por debidamente cumplida dicha carga procesal, no es suficiente con que el recurrente se limite a citar de forma apodíctica los motivos del art. 88 LJCA que pueden dar acceso a la casación, sino que deberá realizar el

60 Así, en el Auto del Tribunal Supremo 5507/2017, de 7 de junio (FJ 2. ${ }^{\circ}$ ): “[A]cierta la Sala en la inadmisión al carecer el escrito de preparación de los requisitos exigidos, a saber, justificar en diferentes y separados apartados la infracción denunciada, su relevancia y el carácter determinante del fallo y también, en especial, dedicar una argumentación específica, con singular referencia al caso, de la concurrencia de alguno o algunos de los supuestos que, conforme a los apartados 2 y 3 del art. 88 LJCA, permitan apreciar el interés casacional objetivo. La recurrente no concreta la infracción normativa y/o jurisprudencial pretendida, ni menciona de manera expresa ninguno de los supuestos del artículo 88 LJCA, apartados 2 y 3 , ni hace la más mínima referencia a la concurrencia del interés casacional". 
imprescindible desarrollo argumental referente a las razones por las que entiende que concurren tales motivos ${ }^{61}$.

Merece la pena detenerse aquí en una cuestión de capital interés, ya no solo para la salvaguarda de los principios de legalidad y de seguridad jurídica, sino para el propio aseguramiento de las garantías específicamente procesales y de la función nomofiláctica de la casación que la reforma ha venido a asegurar. Se trata de la publicidad, a través de la página web del Tribunal Supremo, a que se refiere el art. 90.7 LJCA respecto de los autos de admisión de los recursos de casación. Además, la Sala Tercera deberá hacer público, con periodicidad semestral, y a través de dicha página web y de la publicación en el Boletín Oficial del Estado, el listado de los recursos de casación admitidos a trámite, con una sucinta mención de la norma o normas que serán objeto de interpretación y de la programación para su resolución.

Los operadores jurídicos podrían guiarse así por la determinación de las cuestiones que, a juicio del Tribunal, puedan suscitar interés para la formación de jurisprudencia. Esta pauta puede revestir aún mayor interés por la variante composición de la Sala de admisiones, que se puede traducir en cambios constantes en la interpretación de los ya de por sí jurídicamente indeterminados criterios de admisión ${ }^{62}$. Lo cierto es, sin embargo, que la especificidad de la relevancia social que pueda tener cada asunto y la escueta referencia en las publicaciones periódicas a las normas debatidas hacen que, en la inmensa mayoría de los supuestos, los litigantes no puedan tener una expectativa clara sobre los casos en que la admisión del recurso sería razonable.

b) La inadmisión: el debate en torno a la motivación suficiente.

La inadmisión del recurso de casación adoptará, en general, la forma de providencia, que únicamente indicará la concurrencia de la circunstancia que justifica la decisión en tal sentido: la ausencia de los requisitos reglados de plazo, legitimación o recurribilidad de la resolución impugnada, el incumplimiento de cualquiera de las exigencias que el art. 89.2 LJCA prevé para el escrito de preparación, la irrelevancia de las infracciones

61 En este sentido, entre otros muchos, vid. Auto del Tribunal Supremo 4150/2019, de 4 de abril (FJ 2. ${ }^{\circ}$ ).

62 LOZANO CUTANDA, Blanca: "La reforma del recurso de casación contenciosoadministrativo por la Ley Orgánica 7/2015: análisis de sus novedades". En: Actualidad Administrativa, núm. 11, Sección Actualidad, 2015. 
denunciadas para la formación del juicio o la carencia en el recurso del interés casacional objetivo para la formación de jurisprudencia (art. 90.4 LJCA). Aunque este tipo de resoluciones pueda justificar el debate en torno al derecho de los recurrentes a obtener una resolución motivada conforme a las exigencias de la tutela judicial efectiva ${ }^{63}$, lo cierto es que una larga y consolidada jurisprudencia constitucional ha descartado la existencia de un pretendido derecho fundamental a una extensión determinada de la motivación, siempre que pueda deducirse que el razonamiento judicial responde a criterios jurídicos y lógicos, cualquiera que sea la brevedad y concisión de la decisión adoptada, incluso en los casos de motivación por remisión ${ }^{64}$. Una motivación exhaustiva en torno a la falta de interés objetivo en cada uno de los argumentos contenidos en el recurso podría exigir una respuesta tan extensa como la misma resolución del conflicto, lo que haría perder a la reforma su finalidad. Cuestión distinta es que, atendiendo a las características concretas de cada asunto, la providencia de inadmisión pueda hacer mención, con más o menos detalle, a las razones concretas de por qué el recurso no reviste interés casacional ${ }^{65}$.

63 En opinión de TORRES-FERNÁNDEZ NIETO, Juan José: "Régimen legal de la admisión e inadmisión en el nuevo recurso de casación contencioso-administrativo", Abogacía, 22 de abril de 2016, el art. 90.4 LJCA "puede dar lugar a que quien ha preparado el escrito basado en la existencia de interés casacional objetivo para la formación de jurisprudencia obtenga una providencia de inadmisión que diga, escuetamente, que no tiene interés casacional objetivo para dicha formación [...] Una información sucinta, máxime en tanto no hay un cuerpo de doctrina basado en autos de admisión, creo que sería necesaria y, además, útil como herramienta de colaboración de los operadores jurídicos con la Sala".

64 Entre otras, Sentencias del Tribunal Constitucional 68/2011, de 16 de mayo (FJ 4..$^{\circ}$ ); 108/2001, de 23 de abril (FJ 2. ${ }^{\circ}$ ); 13/2001, de 29 de enero (FJ 2. ${ }^{\circ}$ ). Esta doctrina ha sido recogida por el Tribunal Supremo, que ha llegado incluso a adoptar el término de "economía motivadora", que lleva a "no acumular páginas y páginas con digresiones sobre temas, que puede estar implicados pero que nadie discute y que al mismo tiempo podrían esconder en ese bosque los puntos realmente claves. Ese entretenerse en lo obvio, con exuberancia argumentativa y barroquismo razonador, escondiendo lo controvertido, puede ser tan pernicioso en algún caso extremo como la ausencia de motivación". Así, en las Sentencias del Tribunal Supremo 290/2014, de 21 de marzo (FJ 13. ${ }^{\circ}$ ) y 348/2014, de 1 de abril (FJ 3. ${ }^{\circ}$ ). En idéntico sentido, véase la Sentencia del Tribunal Europeo de Derechos Humanos, de 20 de enero de 2015, en el asunto Arribas Antón c. España: " $[\mathrm{N}]$ o puede ir contra el Convenio, el que una jurisdicción superior rechace un recurso limitándose a citar las disposiciones legales previstas en tal procedimiento, en tanto los problemas planteados por el recurso no revistan una trascendencia especial o si el recurso no tuviera suficientes visos de prosperar" (párr. 47).

65 Auto del Tribunal Supremo 2771/2017, de 30 de marzo (FJ 1. ${ }^{\circ}$ ): "[D]e ninguna manera cabe aceptar que la utilización de la forma de providencia sea en sí misma anómala y 
El legislador procesal, consciente de las dudas expuestas en torno a esta exigencia dimanante de la tutela judicial efectiva, ha querido reconocer una serie de circunstancias para las que el umbral mínimo de motivación sea más elevado. Así, la regla general que exige la exteriorización de las razones de inadmisión en forma de providencia quiebra respecto de los asuntos para los que, conforme al art. 88.3 LJCA, se presuma interés casacional objetivo $^{66}$, y en los supuestos en que la Sala de instancia remita el informe favorable a la admisión del recurso a que se refiere el art. 89.5 LJCA. En estos casos, la decisión de inadmisión deberá adoptar la forma de auto, con expresión de los motivos que justifican la decisión.

Contra los autos y las providencias de inadmisión no cabe recurso alguno, a salvo, según las circunstancias, del incidente de nulidad de actuaciones y del ulterior recurso de amparo constitucional.

\section{El escrito de interposición.}

Admitido el recurso, el Letrado de la Administración de Justicia de la Sección de admisiones dictará diligencia de ordenación, en la que ordenará remitir todas las actuaciones a la Sección de la Sala Tercera competente y hará saber a la parte recurrente que dispone de un plazo de treinta días para presentar el escrito de interposición (art. 92.1 LJCA), con la advertencia de que, de no hacerlo, se declarará desierto el recurso.

generadora de indefensión. Muy al contrario, la regla general es que la inadmisión del recurso de casación ha de adoptar la forma de providencia [...] Y no es ésta [sic] una resolución carente de motivación, pues el artículo 90.4 LJCA señala las indicaciones que ha de contener la providencia para explicar las razones de la inadmisión, si bien la propia norma determina que la motivación sea sucinta ("Las providencias de inadmisión únicamente indicarán...”)". Por lo demás, el Auto de 28 de febrero de 2019 puntualiza que "la mera forma de la resolución -providencia y no auto- no es, en sí misma, originadora de lesión del derecho fundamental denunciado, máxime cuando la providencia dictada ha sido motivada conforme al repetido artículo 90.4 LJCA, haciendo saber a su destinatario, de forma inequívoca, las razones de la inadmisión del recurso de casación". En contra de este criterio se ha manifestado SANTAMARÍA PASTOR, cit., p. 47: "[T] odas las resoluciones, de admisión o inadmisión, debieran adoptarse en forma de auto, bien que sucintamente motivado [...] [B]astan unos pocos párrafos para reseñar el objeto del litigio y la cuestión jurídica que plantea, y para razonar a continuación por qué dicha cuestión ofrece, o no, un interés suficiente para justificar una sentencia de fondo del Tribunal Supremo. La cortesía hacia los litigantes, me parece, no exige menos".

66 No obstante, como apunta el Auto del Tribunal Supremo de 30 de marzo de 2017, la forma de auto "ordenada en el artículo 90.3.b) LJCA no resulta exigible cuando se constata que no concurre el presupuesto para que opere la presunción legal que se invoca". 
Como impone el art. 92.3 LJCA, dicho escrito deberá contener, en apartados separados: a) las razones por las que se considera que han sido infringidas las normas o la jurisprudencia señaladas en el escrito de preparación, sin que se pueda añadir otras nuevas y debiendo analizar, y no solo citar, las resoluciones del Tribunal Supremo que puedan resultar expresivas de aquella jurisprudencia ${ }^{67}$, y b) naturalmente, deberá precisarse el sentido de las pretensiones deducidas por la parte y de los pronunciamientos que solicita. Con ello, se evita que el escrito pueda adolecer de sesgos derivados de la transcripción parcial de la jurisprudencia alegada y se delimita el objeto del litigio en línea con lo ya formulado en el escrito de preparación.

En este estadio, la Sala no puede inadmitir sin más un recurso en el que observe alguna tacha sobre los mencionados requisitos, sino que deberá «oír a la parte recurrente sobre el incumplimiento detectado» (art. 90.4 LJCA). Una audiencia sin mayor utilidad que la de verificar el incumplimiento, tras lo cual, la Sección competente ordenará la inadmisión del recurso sin más trámites e impondrá a dicha parte las costas causadas.

En la sustanciación del recurso, se prevé, de oficio o a instancia de cualquiera de las partes mediante otrosí en los escritos de interposición o de oposición, la celebración de vista pública, incluso ante el Pleno de la Sala, salvo que la Sección competente para el debate y fallo entendiera que las características del asunto la hacen innecesaria (apartados 6 y 7 del art. 90 LJCA) ${ }^{68}$.

La sentencia que resuelva el recurso fijará «la interpretación de aquellas normas estatales o la que tenga por establecida o clara de las de la Unión Europea sobre las que, en el auto de admisión a trámite, se consideró necesario el pronunciamiento del Tribunal Supremo» (art. 93.1 LJCA).

67 Por otra parte, el Tribunal Constitucional, en Sentencia 295/2000, de 11 de diciembre, ha entendido que el defecto consistente en la omisión de cita en el escrito de interposición es subsanable, siempre que tal referencia se hubiera hecho previamente en el escrito de preparación.

68 A este respecto, DÍEZ-PICAZO GIMÉNEZ, Ignacio: "La admisión discrecional de asuntos por el Tribunal Supremo". En: Revista de Jurisprudencia, núm. 1, mayo de 2015. pp. 1-7, opina que "[d]ebería permitirse que el Tribunal Supremo acordara, también con cierto grado de discreción, la práctica de una vista oral para su ilustración. Me parece particularmente importante que el Tribunal Supremo recupere [...] la oralidad. Si los asuntos van a ser enjuiciados por el Tribunal Supremo por su relevancia, la vista pública se impone casi como regla. Es una medida sanísima para la vitalidad del Tribunal, para su percepción pública y para el tipo de abogacía que se postula. Debería tratarse, además, de vistas a la anglosajona: los magistrados machacando a preguntas a los abogados". 
Además, con arreglo a dicha doctrina legal, resolverá «las cuestiones $\mathrm{y}$ pretensiones deducidas en el proceso, anulando la sentencia o auto recurrido, en todo o en parte, o confirmándolos», y podrá, cuando venga justificado por su necesidad, ordenar la retroacción de las actuaciones a un momento determinado del procedimiento de instancia para que siga el curso determinado por la ley hasta su culminación.

\section{CONCLUSIONES}

El recurso de casación en el orden contencioso-administrativo ha sido objeto de una importante reforma orientada a conjurar los males sistémicos que padecía con su anterior regulación. El elevado número de asuntos pendientes de tramitar por el Tribunal Supremo y la correlativa dilación en su resolución no solo ponía el riesgo la operatividad del sistema, sino también la adecuada y pronta satisfacción del interés subjetivo de los recurrentes. La progresiva implantación de trabas de acceso a la casación, lejos de solucionar el problema de la sobrecarga de trabajo, impidió que asuntos de importancia cotidiana para el ciudadano atravesaran el umbral del Tribunal Supremo por no alcanzar la altísima cuantía exigida para ello.

Parece haber tomado consciencia el legislador de aquella desatinada carrera de obstáculos y de la larvada desnaturalización del recurso de casación. Un celebrado despertar que nos ha traído una ampliación de los asuntos que potencialmente podrán acceder al conocimiento del Tribunal Supremo, con cambios en los criterios de admisión aplicables y en la forma de plantearlos. Al margen del concreto supuesto y de la conformación del debate casacional en cada caso, es más variada la tipología de asuntos que podrán beneficiarse de una interpretación uniforme por parte del Tribunal Supremo y, con ello, del establecimiento y eventual revisión de pautas fijas para la adecuada defensa de los intereses privados en aquellos casos en que pudiera verse comprometida la seguridad jurídica y la igualdad de trato ante la ley de los justiciables.

No obstante, los cambios, incluidos aquellos que ponen fin a los desaciertos de un sistema perverso de admisión, no están exentos de riesgos. La figura del interés casacional objetivo, como pneuma de la reforma, es ciertamente oscura, y su progresiva y variable definición jurisprudencial no parece calmar el prurito de los ciudadanos de buscar una respuesta a sus legítimas pretensiones en la cúspide del organigrama judicial. Los recurrentes, aun cumpliendo los requisitos de forma y fondo que exige la 
nueva redacción de la LJCA, pueden ver desestimado su recurso si el alto órgano estima que no existe interés casacional objetivo en el caso concreto.

Con todo, la vocación general de la norma no puede abarcar todos y cada uno de los supuestos en que un asunto puede tener interés para la formación de jurisprudencia. El carácter dinámico del ejercicio de la jurisdicción exige que los motivos que indiciariamente pueden tener tal interés se relacionen de forma abierta, pues no puede descartarse añadir otros nuevos o perfilar los ya existentes a partir de la más variada casuística a que se enfrenta diariamente el Tribunal Supremo. Así lo exige la necesidad de compensar las indisociables funciones del recurso de casación.

\section{BIBLIOGRAFÍA}

BETANCOR, Andrés: La revisión casacional de la prueba en el contencioso-administrativo. Cívitas, Madrid, 2012.

BUJOSA VADELL, Lorenzo; NIEVA FENOLL, Jordi (dirs.): Nociones preliminares de Derecho Procesal Civil. Atelier, Barcelona, 2015.

CALAMANDREI, Piero: La casación civil. Editorial Bibliográfica Argentina, Buenos Aires, 1945.

CANCER MINCHOT, Pilar: "La nueva casación contenciosa: dudas interpretativas que suscitan las sentencias y autos susceptibles de recurso". En: Actualidad Jurídica Aranzadi, núm. 917, 2016.

- "La nueva casación contenciosa- administrativa: sentencias y autos recurribles. El interés casacional objetivo". En: Revista Aranzadi Doctrinal, núm. 6, 2016, pp. 41-62.

CANCIO FERNÁNDEZ, Raúl César: El nuevo recurso de casación en el orden contencioso-administrativo. Aranzadi, Cizur Menor, 2015.

CANCIO FERNÁNDEZ, R. C.; CAZORLA PRIETO, L. M. (dirs.): El interés casacional objetivo en su interpretación auténtica: pautas hermenéuticas y cuestiones procesales en la nueva casación contenciosa. Aranzadi, Cizur Menor, 2018.

CÓRDOBA CASTROVERDE, Diego: "El nuevo recurso de casación en el orden contencioso-administrativo". En: Revista de Jurisprudencia, 1 de octubre de 2015. 
- "Por un nuevo modelo del recurso de casación en materia contenciosoadministrativo". En: Revista de Jurisprudencia, 1 de diciembre de 2013.

CUDERO BLAS, Jesús: "El recurso de casación por infracción de normas autonómicas". En: Revista de Jurisprudencia, 1 de julio de 2016.

DÍEZ-PICAZO GIMÉNEZ, Ignacio: "La admisión discrecional de asuntos por el Tribunal Supremo". En: Revista de Jurisprudencia, núm. 1, mayo de 2015.

ESCRIBANO TESTAUD, Pedro: "Doctrina jurisprudencial sobre la nueva regulación del recurso de casación”. En: Gabinete Técnico del Tribunal Supremo, julio de 2018.

FERNÁNDEZ FARRERES, G.: "Sobre la eficiencia de la jurisdicción contencioso- administrativa y el nuevo recurso de casación para la formación de jurisprudencia". En: Revista Española de Derecho Administrativo, núm. 174, 2015.

GARCÍA GÓMEZ DE MERCADO, Francisco; YAÑEZ DÍAZ, Carlos; VIZÁN PALOMINO, María: El recurso de casación contenciosoadministrativo conforme a la Ley Orgánica 7/2015. Comares, Granada, 2016.

GONZÁLEZ PÉREZ, Jesús: Comentarios a la Ley de la jurisdicción contencioso-administrativa (8. ${ }^{a}$ ed.). Cívitas, Cizur Menor, 2016.

GONZÁLEZ-VARAS IBÁÑEZ, Santiago José: Tratado de Derecho Administrativo (3. ${ }^{\text {a }}$ ed.) (t. II). Aranzadi, Cizur Menor, 2018.

- "Comentarios al nuevo recurso de casación (1): artículos 86 y 87 de la LJCA tras la Ley Orgánica 7/2015, de 21 de julio". En: Revista Aranzadi Doctrinal, núm. 7, 2016.

- “Comentarios al nuevo recurso de casación (2): artículos 88 y 89 de la LJCA tras la Ley Orgánica 7/2015, de 21 de julio". En: Revista Aranzadi Doctrinal, núm. 8, 2016.

- “Comentarios al nuevo recurso de casación (3): artículos 88 y 89 de la LJCA tras la Ley Orgánica 7/2015, de 21 de julio". En: Revista Aranzadi Doctrinal, núm. 9, 2016.

HINOJOSA MARTÍNEZ, Eduardo: El nuevo recurso de casación contencioso-administrativo. Bosch, Barcelona, 2015. 
HUELÍN MARTÍNEZ DE VELASCO, Joaquín: "El interés objetivo en la nueva casación contencioso-administrativa". En: Anuario de la Facultad de Derecho de la Universidad Autónoma de Madrid, núm. 22, 2018.

- "La nueva casación contencioso-administrativa (primeros pasos)". En: Revista General de Derecho Constitucional, núm. 24, 2017.

LETELIER LOYOLA, Enrique: El derecho fundamental al recurso en el proceso penal. Atelier, Barcelona, 2013.

LOZANO CUTANDA, Blanca: "La reforma del recurso de casación contencioso-administrativo por la Ley Orgánica 7/2015: análisis de sus novedades". En: Actualidad Administrativa, núm. 11, Sección Actualidad, 2015.

MARTÍN VALDIVIA, Salvador María: La jurisdicción contenciosa: análisis práctico. Aranzadi, Cizur Menor, 2016.

MAYOR GÓMEZ, Roberto: "Compendio sobre el recurso de casación contencioso-administrativo introducido por la Ley Orgánica 7/2015, de 21 de julio, por la que se modifica la Ley Orgánica 6/1985, de 1 de julio, del Poder Judicial”. En: Gabilex. Revista del Gabinete Jurídico de la Junta de Comunidades de Castilla-La Mancha, núm. 7, septiembre de 2016.

MESTRE DELGADO, Juan Francisco: "La configuración del recurso de casación en torno al interés casacional". En Baño León, José María (coord.): Memorial para la Reforma del Estado: estudios en homenaje al profesor Santiago Muñoz Machado (t. I). Centro de Estudios Políticos y Constitucionales, Madrid, 2016.

MORENO MOLINA, José Antonio (dir.): Procedimiento y proceso administrativo práctico. La Ley, Madrid, 2006.

MUÑOZ ARANGUREN, Antonio: "La curiosidad del jurista persa y la reforma del recurso de casación contencioso-administrativo". En: Diario La Ley, núm. 8634, de 28 de octubre de 2015.

NIEVA FENOLL, Jordi: Derecho Procesal II: Proceso civil. Tirant lo Blanch, Valencia, 2019.

- La casación civil. Ariel, Barcelona, 2003.

- "La relevancia social de la casación: la importancia del ius litigatoris", en Jurisdicción y proceso. Marcial Pons, Madrid, 2009. 
PENDÁS GARCÍA, Benigno: Ley de la Jurisdicción Contenciosoadministrativa: estudio sistemático. Praxis, Barcelona, 1999.

PENÍN ALEGRE, Clara: "La preparación del recurso de casación: un control escurridizo”. En: Revista Jurídica de Castilla y León, núm. 40, 2016.

PÉREZ ALONSO, Jorge: "El nuevo sistema de casación en el orden contencioso-administrativo operado por la Ley Orgánica 7/2015, de 21 de julio: con la vista puesta en el certiorari estadounidense". En: Diario La Ley, núm. 8621 Sección Doctrina, de 8 de octubre de 2015.

PÉREZ UREÑA, Antonio Alberto: "El nuevo recurso de casación contencioso-administrativo". En: Revista de Jurisprudencia, núm. 1, octubre de 2015.

PICÓ I JUNOY, Joan: Las garantías constitucionales del proceso (2. ${ }^{\mathrm{a}}$ ed.). Bosch, Barcelona, 2012.

RAZQUIN LIZARRAGA, José Antonio: "El recurso de casación en la jurisdicción contencioso-administrativa tras la Ley Orgánica 7/2015”. En: Revista Vasca de Administración Pública, núm. 104, 2016.

RODRÍGUEZ CARBAJO, José Ramón: "Las diez claves de los nuevos recursos de casación contencioso-administrativos". En: Diario La Ley, núm. 8809, 22 de julio de 2016.

RUIZ LÓPEZ, Miguel Ángel: La reforma del recurso de casación contencioso-administrativa. Tirant lo Blanch, Valencia, 2016.

SANTAMARÍA PASTOR, Juan Alfonso: "La orientación legal acerca del interés casacional: excesos y defectos del artículo 88". En: Revista de Administración Pública, núm. 207, 2018.

SOLDEVILA FRAGOSO, Santiago: "Las paradojas de la nueva casación". En: Actualidad administrativa, núm. 10, 2016.

TORRES-FERNÁNDEZ NIETO, Juan José (2016): "Régimen legal de la admisión e inadmisión en el nuevo recurso de casación contenciosoadministrativo". En: Abogacía, 22 de abril de 2016.

TRIANA REYES, Belén (2016): "La que se nos viene encima con la casación contencioso-administrativa”. En: Diario La Ley, núm. 8733, Sección Tribuna, 4 de abril de 2016. 